\title{
Glucose Repression of Enterotoxins A, $B$ and $C$ and Other Extracellular Proteins in Staphylococci in Batch and Continuous Culture
}

\author{
By AUDREY W. JAR VIS AND R. C. LAWRENCE \\ New Zealand Dairy Research Institute, Palmerston North, New Zealand \\ AND G. G. PRITCHARD \\ Massey University, Palmerston North, New Zealand
}

(Received 4 June 1974; revised 26 July 1974)

\begin{abstract}
SUMMARY
The production of enterotoxins, lipase and total extracellular protein by four strains of Staphylococcus aureus grown in batch culture at a controlled $\mathrm{pH}$ of 6.5 in a completely defined medium was markedly reduced by glucose or glycerol constantly maintained at $0 \cdot I \mathrm{M}$. A concomitant increase in the production of deoxyribonuclease, up to I3-fold, showed however that not all extracellular proteins are under the same control mechanism. The presence of glucose and glycerol in the medium also resulted in a rapid increase in the specific growth rate. However, growth of $S$. aureus $\mathbf{S} 6$ in $\mathbf{M g}^{++}$-limited continuous culture showed that glucose repression of enterotoxin $B$ when the growth rate was held constant was more than twice that in batch culture. Therefore glucose repression can occur independently of an increase in growth rate. The specific rate of production of enterotoxin B, lipase, deoxyribonuclease, $\beta$-haemolysin and total extracellular protein by $S$. aureus s6 increased as the growth rate increased from 0.07 to $0.24 \mathrm{~h}^{-1}$. Non-replicating cells grown in the absence of glucose produced considerable amounts of enterotoxin, and production was not repressed by the presence of glucose in the resuspension medium. In contrast, no enterotoxin B or C was obtained from nonreplicating cells grown in the presence of glucose. Chloramphenicol completely inhibited enterotoxin production by non-replicating cells, indicating that synthesis of new protein was required.
\end{abstract}

\section{INTRODUCTION}

The production of enterotoxin B by $S$. aureus $\mathbf{s} 6$ has been reported to be subject to glucose repression (see Morse, Mah \& Dobrogosz, 1969; Morse \& Baldwin, 1971). No investigations have, however, been carried out on strains of staphylococci that produce enterotoxins $\mathbf{A}$ or $\mathbf{C}$. In addition, the above studies on enterotoxin B-producing strains were not carried out under strictly controlled conditions of $\mathrm{pH}$ and the complex media employed may not have been completely free of carbohydrate. Miller \& Fung (1973) used the completely defined 18 amino acid medium devised by Wu \& Bergdoll (197I) and found that glucose repressed enterotoxin B production by strain $\mathrm{s} 6$. However, the $\mathrm{pH}$ was not controlled and the concentration of glucose in the medium did not remain constant, decreasing from I to $0.06 \%$ during the experiment. Repression was much less pronounced than that obtained with the complex medium of Morse et al. (1969), and as the defined medium was increasingly simplified by the deletion of amino acids, repression of enterotoxin B production by glucose correspondingly decreased. 
In the present study, the effect of a constant level (O.I M) of glucose or glycerol on the production of enterotoxins, deoxyribonuclease, lipase and total extracellular protein (TEP) under controlled conditions of $\mathrm{pH}$ and aeration was investigated. Preliminary experiments showed that glucose repression of enterotoxin production by staphylococci grown in batch culture was invariably accompanied by an increase in growth rate. Since growth rate has been considered to be an important factor in determining the production of extracellular enzymes (Coleman, 1967), attempts were made to separate the effect of a change in the rate of growth from the effect of glucose per se on the production of extracellular proteins. The first approach used was to determine the effect of glucose on enterotoxin production by resting cells. Secondly, $S$. aureus $\mathbf{s} 6$ was grown in continuous culture and the production of extracellular proteins in the presence and absence of glucose, without change in growth rate, was investigated.

\section{METHODS}

Organisms. Strains I00, s6 and 361 were kindly supplied by M. S. Bergdoll, strains 22 and 30 were from the International Phage-typing set, and strain 3 was a clinical strain. Enterotoxins $A$ and $C$ and their corresponding antisera were also supplied by $M$. S. Bergdoll. Enterotoxin B and its antiserum were purchased from Makor Chemical Co., Israel.

Medium. The defined amino acid medium 4 (2.08\%) described by Wu \& Bergdoll (197I) (AA medium) was used throughout, except that $0.2 \mathrm{M}$-phosphate buffer $\mathrm{pH} 7.0$ was included in the non-replicating cell experiments. Glucose and glycerol were autoclaved separately, pyruvate was sterilized using a Millipore filter, and these were added to sterile media as required. It was shown in preliminary batch culture experiments that reduced growth was obtained by decreasing the $\mathrm{Mg}^{2+}$ from 0.4 to $0.2 \mathrm{mM}$. This concentration was therefore used in the medium for continuous culture to ensure that $\mathrm{Mg}^{2+}$ was the limiting nutrient. Continuous culture medium contained $0.3 \mathrm{mg}$ silicone antifoam (Dow Corning) $/ \mathrm{ml}$. All experiments were carried out at $37^{\circ} \mathrm{C}$.

Cultural conditions. The inoculum for the fermenter consisted of cells grown for $15 \mathrm{~h}$ on a New Brunswick gyratory shaker, washed and resuspended, all of these operations being carried out in AA medium. The fermenter and its operating procedure have been described elsewhere (Jarvis, Lawrence \& Pritchard, 1973). The following modifications were made for continuous culture. An overflow exit line was put in so that the vessel held I $870 \mathrm{ml}$. Medium was fed in through an air-jacketed port by a Sigma pump set at the required speed. The $\mathrm{pH}$ of the medium was maintained at 6.5 by the addition of $\mathrm{N}-\mathrm{HCl}$ in the absence of glucose or $2 \mathrm{~N}-\mathrm{NaOH}$ in glucose experiments. Dissolved oxygen concentration was maintained at a concentration equivalent to a partial pressure of $30 \mathrm{~mm} \mathrm{Hg}$ as described earlier (Jarvis et al. 1973). The fermenter was inoculated with washed cells from $\mathrm{I} 6 \mathrm{~h}$ shake-cultures which were then grown in batch culture using the same medium as that which would be added during continuous culture, the exit line was opened, and the addition of medium commenced. The dilution rate $(D)$ was calculated as

$$
D=\frac{\text { flow rate }(1 / \mathrm{h})}{\text { volume of culture }(\mathrm{l})} \mathrm{h}^{-1} \text {. }
$$

Samples were taken at 2 to $3 \mathrm{~h}$ intervals through the sampling port, and the supernatants used for the determination of extracellular proteins. At less frequent intervals, $60 \mathrm{ml}$ samples were collected via the exit line for determination of cell dry weights.

Control of glucose concentration. Glucose was determined enzymically by the glucostat method (Calbiochem). It was found experimentally in the fermenter that the utilization of 
$0.294 \mathrm{~g}$ glucose required the addition of $\mathrm{I} \mathrm{ml} 2 \mathrm{~N}-\mathrm{NaOH}$ to maintain $\mathrm{pH}$. By adding glucose manually from a burette it was possible to maintain a glucose concentration of between 0.09 and $O \cdot I \mathrm{I} M$ in batch cultures. When continuous culture was initiated, the glucose inlet from the burette was disconnected. The concentration of glucose in the fermenter was then maintained automatically, since glucose was present in the medium being fed into the fermenter. The concentration of glucose in the incoming medium was adjusted for the particular dilution rate so that the glucose concentration in the fermenter during the steady state was between 0.09 and $0.1 \mathrm{I} \mathrm{M}$.

Measurement of growth. Growth was followed by the determination of the extinction of suitably diluted samples as described earlier (Jarvis et al. 1973). Dry weights were determined by centrifuging samples at $\mathrm{I} 2000 \mathrm{rev} . / \mathrm{min}$ for $\mathrm{I} 0 \mathrm{~min}$ to concentrate the cells. Cells were washed and resuspended in cold distilled water, and duplicate amounts dried in tared aluminium dishes at $105{ }^{\circ} \mathrm{C}$ for $3 \mathrm{~h}$. Specific growth rate $(\mu)$ was given by:

$$
\mu=\frac{\ln E_{t_{2}}-\ln E_{t_{1}}}{t_{2}-t_{1}}
$$

for time $t_{1}$ to $t_{2}$ (Stanier, Doudoroff \& Adelberg, 197I).

Determination of extracellular proteins. Samples of the cultures were centrifuged and I00 $\mu \mathrm{g}$ Merthiolate (Eli Lilly Co.) $/ \mathrm{ml}$ were added to the supernatants, which were then stored at $4{ }^{\circ} \mathrm{C}$. Enterotoxins, lipase, deoxyribonuclease and total extracellular protein determinations were carried out as described elsewhere (Jarvis et al. 1973). $\beta$-Haemolysin titres were determined as described by Chesbro, Heydrick, Martineau \& Perkins (1965).

$$
\frac{d_{p}}{d_{t}}=q_{p} x
$$

where $q_{p}$ is the specific rate of product formation per unit of cell mass, and $x$ is the cell mass and $p$ the product mass at time $t$ (Pirt, 1969). By integration and expansion, the specific rate of product formation per unit cell mass over any given period is given by:

$$
q_{p}=\frac{\text { increase in product }}{\text { increase in cell mass }} \times \text { specific growth rate, }
$$

from which we calculate the specific rate of formation of extracellular protein, $q_{p}$.

Under conditions of continuous culture, the rate of increase in the concentration of a product in the culture depends on the difference between the rate of product formation, and the rate at which the product is being washed out of the fermenter, i.e. the dilution rate. Thus

$$
\frac{\mathrm{d} p}{\mathrm{~d} t}=q_{p} x-D p
$$

where $q_{p}$ is the specific rate of product formation per unit of cell mass, $x$ the concentration of cells, $D$ the dilution rate, and $p$ the concentration of product (Pirt, I969).

In the steady state,

$$
\frac{\mathrm{d} p}{\mathrm{~d} t}=0
$$

Therefore

$$
q_{p} \bar{x}=D \bar{p}
$$




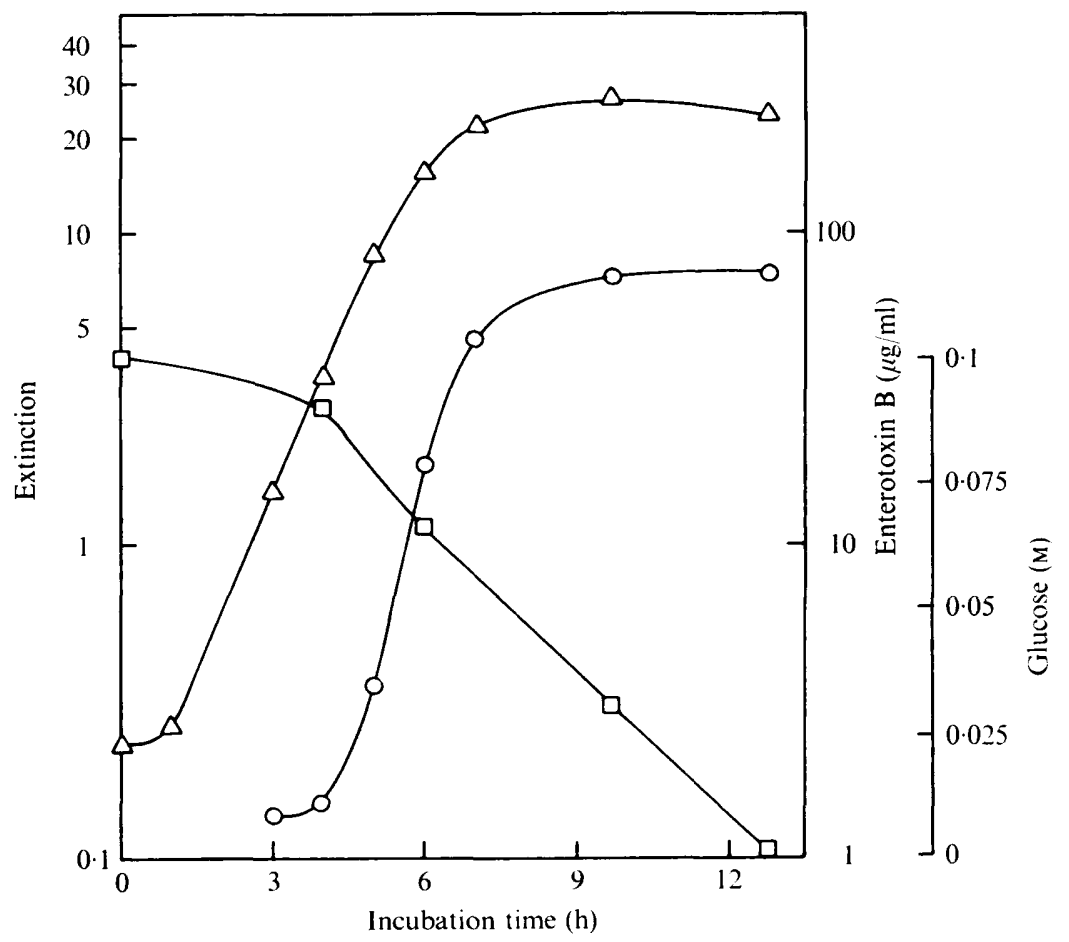

Fig. I. Growth and enterotoxin B production by $S$. aureus $\mathrm{s} 6$ in the fermenter at $\mathrm{pH} 6 \cdot 5$, with an initial concentration of 0. I I M-glucose. $\triangle$, Extinction; $O$, enterotoxin B; $\square$, glucose concentration. The extinctions have been multiplied by the dilution factor.

where $\bar{x}$ and $\bar{p}$ denote the steady state concentration of cells and product respectively. Hence

$$
q_{p}=D \frac{\bar{p}}{\bar{x}}
$$

Non-replicating cells. These were prepared as described by Markus \& Silverman (I969). Sixteen $\mathrm{h}$ cells were washed four times in 0.0I M-phosphate buffer, and resuspended in the appropriate medium so that a dilution of $I$ in 200 gave an extinction of $0 \cdot 20$. This corresponded to approximately $\mathrm{I} 0 \mathrm{mg}$ dry $\mathrm{wt}$ of cells $/ \mathrm{ml}$. Forty $\mathrm{ml} / \mathrm{I} 50 \mathrm{ml}$ flask (glucose and glycerol experiments) or $15 \mathrm{ml} / \mathrm{I} 00 \mathrm{ml}$ flask (chloramphenicol experiments) were shaken at $37^{\circ} \mathrm{C}$ for the times specified.

$\beta$-Galactosidase. Determinations of $\beta$-galactosidase were carried out as described by Eagon (1968). Cells were washed and resuspended in cold distilled water and incubated with $0.2 \mathrm{M}$-sodium phosphate buffer $\mathrm{pH} \mathrm{7.25}$ plus $0.002 \mathrm{M}-0$-nitrophenyl- $\beta$-D-galactopyranoside (ONPG) (Calbiochem). One unit of enzyme was taken as that which hydrolysed I $\mu \mathrm{mol}$ ONPG in $3 \mathrm{~h}$ at $30^{\circ} \mathrm{C}$, using a standard curve ( $\mu$ mol ONP versus $\left.E_{420}\right)$.

\section{RESULTS}

Preliminary shake-flask experiments

The presence of $0 . \mathrm{I} \mathrm{M}$-glucose and $\mathrm{O} . \mathrm{I} \mathrm{M}$-glycerol in the medium greatly decreased the production of enterotoxin, lipase, deoxyribonuclease and TEP by all five strains of staphylococci during $\mathrm{I} 2 \mathrm{~h}$ incubation. The $\mathrm{pH}$ of the medium decreased during growth from 6.5 to 
Table I. Effect of $0 \cdot 1 \mathrm{M}$-glucose and $0 \cdot 1 \mathrm{M}$-glycerol on the production of enterotoxin $A, B$ and $C$ and other extracellular products by staphylococci during $\mathrm{I} 2 \mathrm{~h}$ incubation in batch culture in the fermenter at $\mathrm{pH} 6.5$.

\begin{tabular}{|c|c|c|c|c|c|c|c|c|}
\hline & $\begin{array}{l}\text { Strain } \\
\text { and } \\
\text { entero- } \\
\text { toxin } \\
\text { type }\end{array}$ & Extinction & $\begin{array}{c}\text { Entero- } \\
\text { toxin } \\
(\mu \mathrm{g} / \mathrm{ml})\end{array}$ & $\begin{array}{l}\text { Specific } \\
\text { rate of } \\
\text { entero- } \\
\text { toxin } \\
\text { produc- } \\
\text { tion } \\
\quad\left(q_{p}\right)\end{array}$ & $\begin{array}{c}\text { TEP } \\
(\mathrm{mg} / \mathrm{ml})\end{array}$ & $\begin{array}{c}\text { Lipase } \\
\text { (units } / \mathrm{ml} \text { ) }\end{array}$ & $\begin{array}{l}\text { Deoxy- } \\
\text { ribo- } \\
\text { nuclease } \\
\text { (units } / \mathrm{ml} \text { ) }\end{array}$ & $\begin{array}{c}\text { Specific } \\
\text { growth } \\
\text { rate } \\
(\mu)\end{array}$ \\
\hline $\begin{array}{l}\text { Control } \\
\text { O. I M-Glucose }\end{array}$ & $\begin{array}{l}100 \mathrm{~A} \\
100 \mathrm{~A}\end{array}$ & $\begin{array}{l}26 \cdot 8 \\
14 \cdot 2\end{array}$ & $\begin{array}{r}32 \\
3\end{array}$ & $\begin{array}{l}0.21 \\
0.12\end{array}$ & $\begin{array}{l}0.05 \\
0.05\end{array}$ & $\begin{array}{l}5 \\
0\end{array}$ & $\begin{array}{l}5 \\
8\end{array}$ & $\begin{array}{l}0.38 \\
0.71\end{array}$ \\
\hline $\begin{array}{l}\text { Control } \\
\text { O.I M-Glucose } \\
\text { O. I M-Glycerol }\end{array}$ & $\begin{array}{ll}s 6 & B \\
s 6 & B \\
s 6 & B\end{array}$ & $\begin{array}{l}25 \cdot 8 \\
36 \\
35\end{array}$ & $\begin{array}{r}129 \\
5 I \\
29\end{array}$ & $\begin{array}{l}2 \cdot I \\
1 \cdot 3 \\
I \cdot 0\end{array}$ & $\begin{array}{l}0.84 \\
0.46 \\
0.55\end{array}$ & $\begin{array}{r}240 \\
147 \\
34\end{array}$ & $\begin{array}{r}37 \\
500 \\
450\end{array}$ & $\begin{array}{l}0.46 \\
0.91 \\
0.82\end{array}$ \\
\hline $\begin{array}{l}\text { Control } \\
\text { o. I M-Glucose }\end{array}$ & $\begin{array}{l}361 C \\
361 C\end{array}$ & $\begin{array}{l}22 \cdot 8 \\
24 \cdot 6\end{array}$ & $\begin{array}{l}53 \\
15\end{array}$ & $\begin{array}{l}0.59 \\
0.16\end{array}$ & $\begin{array}{l}1 \cdot 02 \\
0 \cdot 36\end{array}$ & $\begin{array}{l}320 \\
201\end{array}$ & $\begin{array}{r}8 \\
\mathrm{I} 4\end{array}$ & $\begin{array}{l}0.47 \\
0.80\end{array}$ \\
\hline $\begin{array}{l}\text { Control } \\
\text { O. I M-Glucose } \\
\text { O. I M-Glycerol }\end{array}$ & $\begin{array}{ll}30 & \mathrm{~B} \\
30 & \mathrm{~B} \\
30 & \mathrm{~B}\end{array}$ & $\begin{array}{l}22 \cdot 4 \\
28 \cdot 8 \\
26 \cdot 4\end{array}$ & $\begin{array}{r}136 \\
26 \\
35\end{array}$ & $\begin{array}{l}2 \cdot 8 \\
1 \cdot 0 \\
0 \cdot 9\end{array}$ & $\begin{array}{l}0.89 \\
0.70 \\
0.68\end{array}$ & $\begin{array}{r}17 \\
7 \\
13\end{array}$ & $\begin{array}{r}25 \\
125 \\
246\end{array}$ & $\begin{array}{l}0.78 \\
1 \cdot 13 \\
1 \cdot 18\end{array}$ \\
\hline
\end{tabular}

between 5.0 and 5.6 . The effect of 0.1 M-pyruvate on the other hand could be readily distinguished from a $\mathrm{pH}$ effect, since its addition to the medium did not result in a significant change in $\mathrm{pH}$ during incubation. Pyruvate stimulated the production of deoxyribonuclease for all strains, but the effect on other extracellular proteins varied greatly between strains. Strains s6 and 36I showed increases in enterotoxin, lipase and TEP production, strain 100 showed a decrease in enterotoxin and lipase and no change in TEP, and strain 3 showed no change in enterotoxin or lipase but an increase in TEP. The presence of glucose, glycerol and pyruvate increased the growth rate for all five strains.

The results did not indicate whether the differences in the effects of these compounds were due to the specific carbon compound used, or to the resultant $\mathrm{pH}$ developed in the medium. Therefore the effect of glucose and glycerol was investigated in batch culture under conditions of controlled $\mathrm{pH}$.

\section{The effect of glucose and glycerol on the production of extracellular proteins in batch culture under controlled conditions}

Figure I shows the effect of an initial concentration of $0 \cdot$ I I M-glucose on the production of enterotoxin B by strain $\mathrm{s} 6$ during $\mathrm{I} 2 \mathrm{~h}$, and the utilization of glucose during that period. Enterotoxin concentrations reached $50 \mu \mathrm{g} / \mathrm{ml}$ at a time when $0.05 \mathrm{M}$-glucose still remained in the medium. However, the final concentration of enterotoxin was $74 \%$ lower than in a control experiment without glucose. At the same time the specific growth rate was $85 \%$ greater in the glucose experiment.

When a constant glucose or glycerol concentration of $\mathrm{O}^{\circ} \mathrm{I} \mathrm{M}$ was maintained in the fermenter, the specific rate of production of enterotoxin per unit cell mass per unit time $\left(q_{p}\right)$ was reduced for all four strains (Table $\mathrm{I}$ ). These specific rates of production were calculated for the times of maximum enterotoxin production, e.g. 6 to $9 \mathrm{~h}$ for the control experiment and 4 to $6 \mathrm{~h}$ for the glucose experiment for strain s6 (Fig. 2). The final concentrations in the medium of enterotoxin, lipase and TEP were also decreased. In contrast, deoxy- 


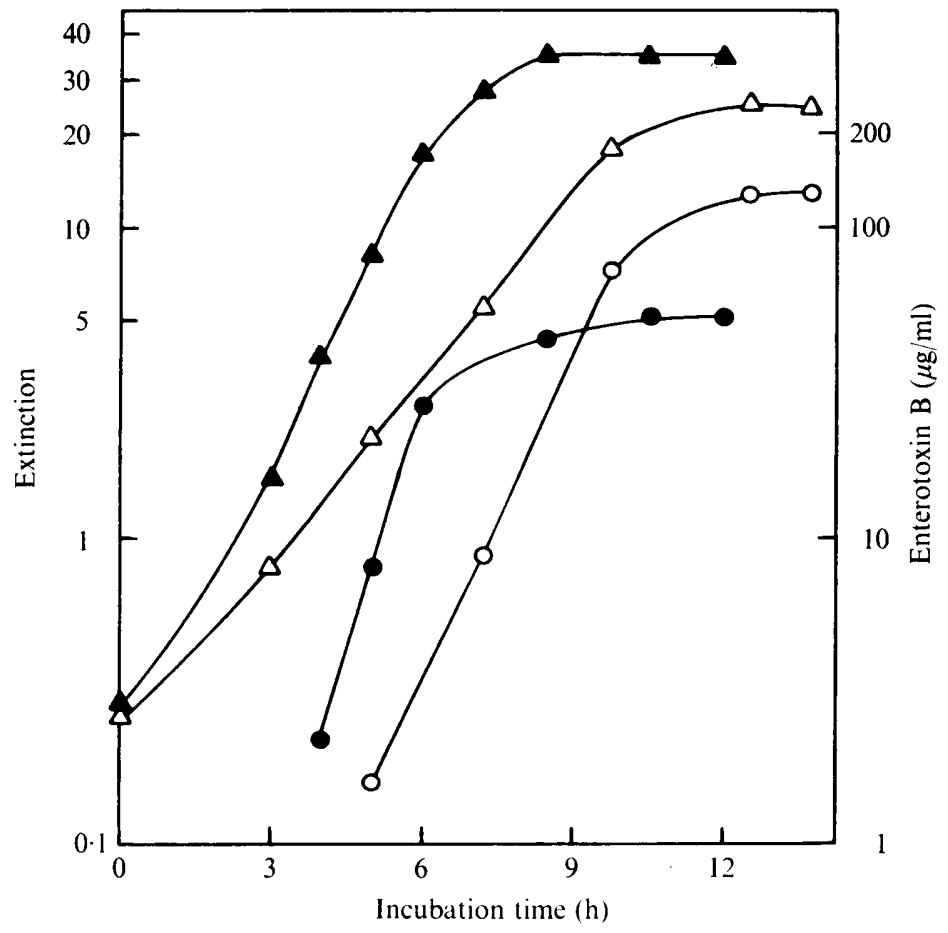

Fig. 2. Effect of $0.1 \mathrm{M}$-glucose on growth and enterotoxin B production by $S$. aureus $\mathbf{s} 6$ in the fermenter at $\mathrm{pH} 6.5 . \Delta, \Delta$, Extinction; $\bigcirc, \boldsymbol{\theta}$, enterotoxin B. Open symbols indicate control, solid symbols indicate $0 \cdot 1 \mathrm{M}$-glucose. The extinctions have been multiplied by the dilution factor.

ribonuclease production in the presence of glucose was increased 13- and 5-fold with strains s6 and 30 , respectively.

The specific growth rate was invariably increased in the presence of glucose, as illustrated for strain s6 in Fig. 2. There was a corresponding decrease in the duration of the exponential growth phase and also in the time during which enterotoxins were produced. In the fermenter the increase in growth rate in the presence of glucose or glycerol was much greater than in shake-flasks, where the rapid fall in $\mathrm{pH}$ affected the growth rate. The final extinction of the cultures of all strains when grown in shake-flasks in the presence of glucose or glycerol was also much less than in control flasks containing no carbohydrate, whereas the reverse was frequently true in the fermenter.

\section{Effect of glucose on enterotoxin production by non-replicating cells}

Fermenter and shake-flask experiments showed that reduced enterotoxin production in the presence of glucose was always accompanied by an increase in specific growth rate. Experiments with non-replicating cells were undertaken in an attempt to determine whether glucose repressed the production of enterotoxins under conditions where there was no increase in growth rate.

It has been suggested that the repression of enterotoxin production by glucose is due to catabolite repression (Morse et al. 1969). Therefore, in the non-replicating cell experiments, galactose $(0.05 \mathrm{M})$ was added to the shake-flasks to induce the formation of $\beta$-galactosidase, as this allowed comparisons to be made between repression of enterotoxins and of an enzyme 
Table 2. The effect of glucose on the production of enterotoxin and $\beta$-galactosidase by nonreplicating cells of staphylococci during $2 h$ incubation

\begin{tabular}{cl}
$\begin{array}{c}\text { Strain and } \\
\text { enterotoxin } \\
\text { type }\end{array}$ & \multicolumn{1}{c}{$\begin{array}{c}\text { Growth } \\
\text { medium }\end{array}$} \\
100 A & AA \\
100 A & AA \\
100 A & AA+ glucose \\
I00 A & AA + glucose \\
s6 B & AA \\
s6 B & AA \\
s6 B & AA+glucose \\
s6 B & AA+ glucose \\
36I C & AA \\
361 C & AA \\
36I C & AA + glucose \\
36I C & AA + glucose
\end{tabular}

Resuspending
medium
AA
AA+glucose
AA
AA+glucose
AA
AA+glucose
AA
AA +glucose
AA
AA + glucose
AA
AA + glucose

$\begin{array}{cc}\begin{array}{c}\text { Enterotoxin } \\ (\mu \mathrm{g} / \mathrm{ml})\end{array} & \begin{array}{c}\beta \text {-Galactosidase } \\ \text { (units) }\end{array} \\ 2 & 0.058 \\ 2 & 0.003 \\ 2 & 0.008 \\ 2 & 0.001 \\ 29 & 0.022 \\ 40 & 0.001 \\ 2 & 0.001 \\ 2 & 0 \\ 22 & 0.041 \\ 24 & 0.005 \\ \text { ND } & 0.006 \\ \text { ND } & 0\end{array}$

ND, Not detectable.

Cells were grown in AA medium in the presence or absence of glucose and resuspended in buffered AA medium with or without glucose.

which is known to be subject to catabolite repression (Blumenthal, 1972). This concentration of galactose was shown to have no inhibitory effect on the production of enterotoxin by non-replicating cells. When glucose was added to non-replicating cells, the utilization of glucose resulted in a marked decrease in $\mathrm{pH}$ from 6.5 to 5.2 . Therefore, $0.2 \mathrm{M}$-phosphate buffer $(\mathrm{pH} 7 \cdot 0)$ was added for $\mathrm{pH}$ control, although this decreased enterotoxin production by almost $40 \%$. Under the above conditions there was no significant cell multiplication.

Table 2 shows the effects of $0 \cdot 1$ M-glucose on the production of enterotoxins and $\beta$ galactosidase by non-replicating cells of strains $100, s 6$ and $36 \mathrm{I}$. Cells grown in the absence of glucose, and resuspended, produced enterotoxin and $\beta$-galactosidase. The addition of $0 \cdot I$ M-glucose to the resuspending medium increased the production of enterotoxin $B$, and did not affect the production of enterotoxins $A$ and $C$. However, the production of $\beta$-galactosidase was almost completely repressed for all three strains.

When cells were grown in medium containing glucose, and resuspended with or without glucose, almost no enterotoxin B or $C$ was produced by strains s6 and 36I respectively. Similar results were found for two other enterotoxin B-producing strains. In contrast, however, growing strain 100 in glucose did not appear to affect the ability of resuspended cells to produce enterotoxin A. The addition of glucose to the growth medium greatly reduced $\beta$-galactosidase production by non-replicating cells for all three strains.

\section{Effect of chloramphenicol on the production of enterotoxin $B$ by non-replicating cells}

It was possible that the production of enterotoxin by non-replicating cells that had been grown in the absence of glucose might be due to the presence of an enterotoxin precursor, as suggested by Markus \& Silverman (1969). However, the addition of $100 \mu \mathrm{g}$ chloramphenicol/ $\mathrm{ml}$ to non-replicating cells, grown in the absence of glucose, completely repressed the production of enterotoxin B by strain s6, indicating that new protein synthesis was required.

Since these results with strain s6 conflicted with those of Markus \& Silverman (1969), the effect of chloramphenicol on the non-replicating cells of four further strains of $S$. aureus was investigated. The cells were harvested from the late exponential and stationary phases of 
Table 3. Effect of chloramphenicol on enterotoxin production by non-replicating cells of 5 strains of $S$. aureus in AA medium during 4 h incubation

\begin{tabular}{|c|c|c|c|c|c|}
\hline & \multirow{3}{*}{$\begin{array}{l}\text { Strain and } \\
\text { enterotoxin } \\
\text { type }\end{array}$} & \multicolumn{4}{|c|}{ Enterotoxin $(\mu \mathrm{g} / \mathrm{ml})$} \\
\hline & & \multicolumn{2}{|c|}{ Exponential phase cells } & \multicolumn{2}{|c|}{ Stationary phase cells } \\
\hline & & $\mathrm{N}$ medium & $\begin{array}{l}\mathrm{N} \text {-free } \\
\text { medium }\end{array}$ & $\mathrm{N}$ medium & $\begin{array}{l}\text { N-free } \\
\text { medium }\end{array}$ \\
\hline Control & $100 \mathrm{~A}$ & $7 \cdot 5$ & 0.5 & I I & 0.5 \\
\hline & $100 \mathrm{~A}$ & 0 & 0 & 0.5 & 0.5 \\
\hline Control & $22 \mathrm{~A}$ & $6 \cdot 3$ & 3 & 6 & 0 \\
\hline $\mathrm{Cm}$ & $22 \mathrm{~A}$ & 0 & 0 & 0 & 0 \\
\hline Control & $22 \mathrm{~B}$ & I 20 & 3 & 135 & 2 \\
\hline $\mathrm{Cm}$ & $22 \mathrm{~B}$ & 0 & I & I & I \\
\hline Control & s6 B & 270 & 5 & 63 & 5 \\
\hline $\mathrm{Cm}$ & s6 B & 0 & 2 & $\mathbf{I}$ & 2 \\
\hline Control & $3 \mathrm{C}$ & 152 & 2 & 33 & 0 \\
\hline $\mathrm{Cm}$ & $3 \mathrm{C}$ & 0 & 0.5 & 0 & 0 \\
\hline Control & 36I $\mathrm{C}$ & 22 & 2 & 20 & 0 \\
\hline $\mathrm{Cm}$ & 36I $\mathrm{C}$ & 0 & 2 & 0 & 0 \\
\hline
\end{tabular}

$\mathrm{Cm}$, roo $\mu \mathrm{g}$ chloramphenicol $/ \mathrm{ml}$.

growth, and resuspended in $\mathrm{N}$-containing and $\mathrm{N}$-free media. After $4 \mathrm{~h}$ incubation on the shaker, all strains in the absence of chloramphenicol produced an appreciable amount of enterotoxin in the $\mathrm{N}$-containing medium (Table 3) whereas only very low levels of enterotoxin were detected in the $\mathrm{N}$-free medium. In both media, however, the addition of chloramphenicol almost completely inhibited enterotoxin production, indicating that no significant amount of enterotoxin precursor was present in the five strains tested.

\section{The effect of glucose on production of enterotoxin $B$ and other extracellular proteins in continuous culture}

The results obtained with non-replicating cells did not enable a clear distinction to be made between the effect of a change in growth rate and of glucose per se on enterotoxin production. The effect of glucose on the production of extracellular proteins at constant growth rate was therefore determined in continuous culture. In the presence of glucose, there were marked transient oscillations in extinction, enterotoxin B and TEP before the steady state was established. When the dilution rate was $0.24 \mathrm{~h}^{-1}$, a steady state was achieved only after approximately 7 residence times $(28 \mathrm{~h})$ in the presence of glucose, as compared with approximately 4 residence times $(\mathrm{I} 7 \mathrm{~h})$ in the control experiment without glucose (Fig. 3). Similar oscillations have been reported for other organisms (Yano \& Koga, 1973) and were considered to result from end-product inhibition.

The production of enterotoxin B and TEP throughout growth is shown for dilution rate $0.24 \mathrm{~h}^{-1}$ in Fig. 3. Lipase, deoxyribonuclease, lysozyme and $\beta$-haemolysin production were also followed throughout growth (Table 4). The determination of $\beta$-haemolysin was carried out because the genetic determinants for enterotoxin B and $\beta$-haemolysin have recently been reported to be on the same plasmid (Dornbusch \& Hallander,1973) and it was considered that these two proteins might therefore respond similarly to the presence of glucose.

At a dilution rate of $0.07 \mathrm{~h}^{-1}$, the addition of glucose to the medium reduced the specific rates of production of enterotoxin B by $70 \%$ and TEP by $60 \%$ (Table 4 ). The specific rate of 


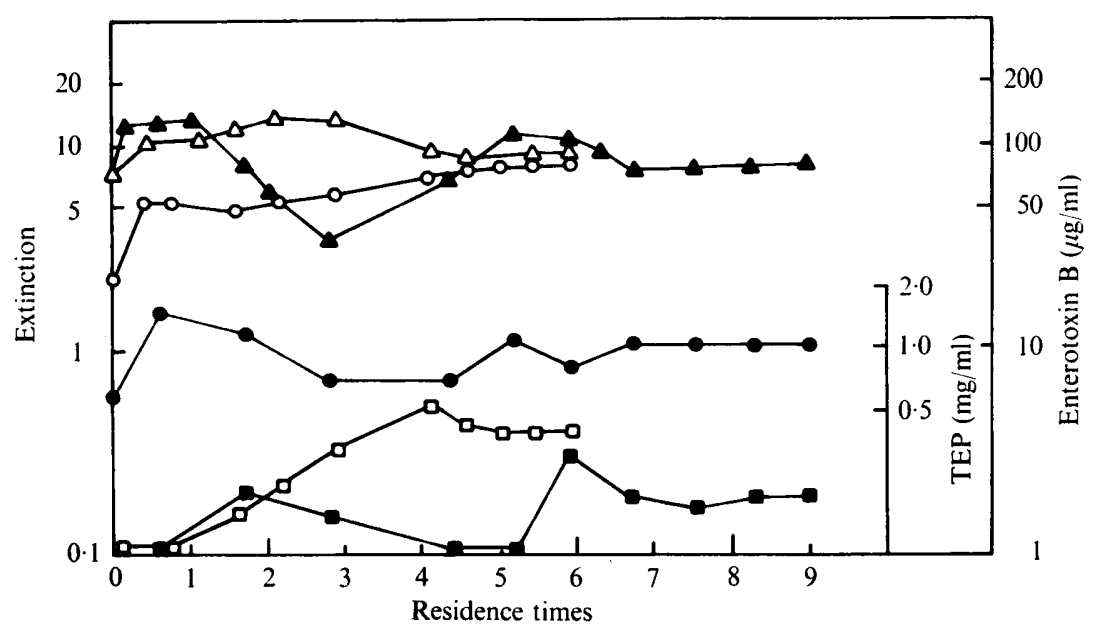

Fig. 3. Extinction $(\triangle, \mathbf{A})$ and enterotoxin $\mathbf{B}(\bigcirc, \ominus)$ and TEP $(\square, \boldsymbol{\sigma})$ production by strain s6 in continuous culture; dilution rate $0.24 \mathrm{~h}^{-1}$, residence time $4.2 \mathrm{~h}$, without (open symbols) and with (solid symbols) $0.1 \mathrm{M}$-glucose. The extinctions have been multiplied by the dilution factor.

Table 4. Effect of O.I M-glucose on the production of enterotoxin B and other extracellular proteins by $\mathrm{S}$. aureus $\mathrm{s} 6$ in $\mathrm{Mg}^{++}$-limited culture

Cells $(\mathrm{mg} / \mathrm{ml})$

Enterotoxin B $(\mu \mathrm{g} / \mathrm{ml})$

Enterotoxin B $\left(q_{p}\right)$

TEP $(\mathrm{mg} / \mathrm{ml})$

TEP $\left(q_{p}\right)$

Lipase (units $/ \mathrm{ml}$ )

Lipase $\left(q_{p}\right)$

Deoxyribonuclease (units $/ \mathrm{ml}$ )

Deoxyribonuclease $\left(q_{p}\right)$

Lysozyme (units $/ \mathrm{ml}$ )

Lysozyme $\left(q_{p}\right)$

$\beta$-Haemolysin (titre)

\begin{tabular}{|c|c|c|c|}
\hline \multicolumn{4}{|c|}{ Dilution rate $\left(\mathrm{h}^{-1}\right)$} \\
\hline \multicolumn{2}{|c|}{0.07} & \multicolumn{2}{|c|}{0.24} \\
\hline Control* & O. I M-Glucose & Control* & o. I M-Glucose \\
\hline $3 \cdot 24$ & 3.49 & $I \cdot 66$ & $I \cdot 50$ \\
\hline 123 & 39 & 80 & I I \\
\hline $2 \cdot 66$ & 0.77 & II $\cdot 50$ & $\mathrm{I} \cdot 75$ \\
\hline$I \cdot 64$ & 0.65 & 0.39 & 0.18 \\
\hline 0.035 & 0.013 & 0.056 & 0.029 \\
\hline 161 & 76 & 123 & $5 I$ \\
\hline $3 \cdot 46$ & $I \cdot 52$ & $17 \cdot 82$ & $8 \cdot 20$ \\
\hline 56 & 56 & 23 & 26 \\
\hline$I \cdot 2 I$ & $I \cdot 12$ & $3 \cdot 33$ & $4 \cdot 16$ \\
\hline 0.55 & 0.35 & 0 & 0 \\
\hline 0.012 & 0.006 & 0 & 0 \\
\hline$I / 64$ & $\mathrm{I} / 4$ & $\mathrm{I} / 32$ & 0 \\
\hline
\end{tabular}

* Indicates medium without glucose.

lipase production was decreased by $56 \%$ and that of lysozyme production was decreased by $50 \%$. The $\beta$-haemolysin titre was reduced I6-fold in the presence of glucose. In contrast, glucose had no significant effect on deoxyribonuclease production.

At the higher dilution rate of $0.24 \mathrm{~h}^{-1}$, glucose reduced the specific rates of production of enterotoxin, TEP and lipase by 85,50 and $55 \%$, respectively (Table 4 ). The presence of glucose completely inhibited the production of $\beta$-haemolysin, as compared with a titre of $1 / 32$ in the control without glucose. By contrast, the production of deoxyribonuclease was slightly stimulated by glucose. 


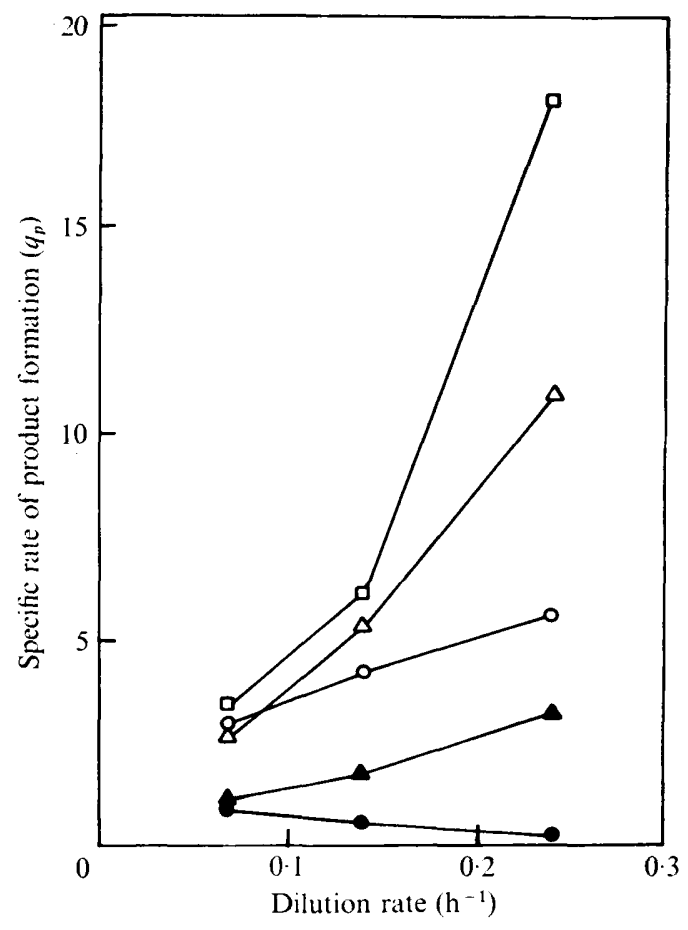

Fig. 4. Effect of dilution rate on the specific rate of formation of the following proteins by strain s6: enterotoxin B $(\triangle)$; TEP $(\times 100)(O)$; lipase $(\square)$; deoxyribonuclease $(\Delta)$; lysozyme $(\times 100)(\bullet)$.

The effect of growth rate on the production of enterotoxin $B$ and other extracellular proteins in continuous culture

The production of enterotoxin B and other extracellular proteins was determined in continuous culture using AA medium in the absence of glucose at three different growth rates to investigate whether growth rate per se was important, in determining the production of enterotoxin. The three dilution rates used were $0 \cdot 07,0 \cdot 14$ and $0.24 \mathrm{~h}^{-1}$, corresponding to residence times of $14 \cdot 3,7 \cdot \mathrm{I}$ and $4 \cdot 2 \mathrm{~h}$ respectively. At each dilution rate, the fermentation was continued for at least two residence times after the steady state had been established, as indicated by constant extinction values. In the steady state in continuous culture, the growth rate $(\mu)$ equals the dilution rate $(D)$. When the growth rate was increased from 0.07 to 0.24 there was a fourfold increase in the specific rate of enterotoxin production, from 2.66 to I I. $5 \mu \mathrm{g} / \mathrm{mg}$ cells $/ \mathrm{h}$ (Fig. 4). The specific rate of production of deoxyribonuclease and lipase also increased. Lysozyme was the only extracellular protein assayed which showed a decrease in the specific rate of production as growth rate increased (Table 5). The concentration of cells in the steady state decreased from 3.24 to $\mathrm{I} .66 \mathrm{mg}$ dry $\mathrm{wt} / \mathrm{ml}$ as the growth rate was increased from 0.07 to $0.24 \mathrm{~h}^{-1}$. This is in agreement with the theoretical predictions of Herbert, Elsworth \& Telling (1956) that as the dilution rate increases the concentration of organisms falls. 
Table 5. Effect of dilution rate on the production of enterotoxin $B$ and other extracellular proteins by $\mathrm{S}$. aureus $\mathrm{s} 6$ in $\mathrm{Mg}^{2+-}$-limited culture

\begin{tabular}{lccc} 
& \multicolumn{3}{c}{ Dilution rate $\left(\mathrm{h}^{-1}\right)$} \\
\cline { 2 - 4 } & 0.07 & 0.14 & 0.24 \\
Cells $(\mathrm{mg} / \mathrm{ml})$ & 3.24 & 2.30 & $\mathrm{I} \cdot 66$ \\
Enterotoxin B $(\mu \mathrm{g} / \mathrm{ml})$ & 123 & 88 & 80 \\
Enterotoxin B $\left(q_{p}\right)$ & 2.66 & 5.36 & $\mathrm{I} \cdot 50$ \\
TEP $(\mathrm{mg} / \mathrm{ml})$ & $\mathrm{I} \cdot 64$ & 0.72 & 0.39 \\
TEP $\left(q_{p}\right)$ & 0.035 & 0.043 & 0.056 \\
Lipase $($ units/ml) & $16 \mathrm{I}$ & 100 & 123 \\
Lipase $\left(q_{p}\right)$ & 3.46 & $6 \cdot 10$ & 17.82 \\
Deoxyribonuclease $($ units $/ \mathrm{ml})$ & 56 & 26 & 23 \\
Deoxyribonuclease $\left(q_{p}\right)$ & $\mathrm{I} \cdot 2 \mathrm{I}$ & 1.59 & 3.33 \\
Lysozyme (units/ml) & 0.55 & 0.10 & 0 \\
Lysozyme $\left(q_{p}\right)$ & 0.012 & 0.006 & 0
\end{tabular}

\section{DISCUSSION}

Preliminary experiments in shake-flasks showed that glucose and glycerol almost completely repressed enterotoxin production and caused a marked decrease in the $\mathrm{pH}$ of the medium. When the $\mathrm{pH}$ in the fermenter was maintained at 6.5 and glucose or glycerol concentrations kept constant, repression of enterotoxins, lipase and TEP still occurred although to a lesser extent than in the shake-flask experiments. The almost total repression by glucose or glycerol in the shake-flask experiments was therefore only partly due to the decrease in $\mathrm{pH}$. This is not in complete agreement with the conclusion of Metzger, Johnson, Collins \& McGann (1973) that $\mathrm{pH}$ rather than glucose is the limiting factor in the release of enterotoxin $\mathrm{B}$ by strain s6. However, the initial concentration of glucose in their fermenter was only $0.2 \%$ and this was not maintained throughout the fermentation. The simultaneous repression of enterotoxins, lipase and TEP by glucose and glycerol suggests that some extracellular proteins may be under a common regulatory control, in agreement with Omenn \& Friedman (1970) and Forsgren, Nordström, Philipson \& Sjöquist (197I). However, the finding that glucose did not repress (and sometimes markedly stimulated) deoxyribonuclease production when it repressed other extracellular enzymes indicates that this is not true for all extracellular proteins produced by staphylococci.

The presence of glucose or glycerol in batch cultures altered the cell yield and the period of time during which enterotoxins were produced. The reduction in the specific rate of enterotoxin production per unit cell mass per unit time indicates, however, that the effect of glucose or glycerol was not due to this alteration in growth pattern. Mandelstam(1962) and Gallo \& Katz (1972) reported that the most effective repressers are those that produce the most rapid growth rates. In this investigation the results obtained in continuous culture show that glucose repression can occur without an increase in growth rate. Indeed, glucose repression of the specific rate of enterotoxin production by $S$. aureus $\mathrm{s} 6$ at constant growth rate in continuous culture was more than twice that in batch culture.

The production of enterotoxin B and other extracellular proteins has been studied in continuous culture at three different dilution rates. The specific rate of enterotoxin production increased more than fourfold when the growth rate was increased from 0.07 to $0.24 \mathrm{~h}^{-1}$. The highest rate of enterotoxin production per cell obtained was similar to the maximum value attained during batch culture when both rates are related to extinction. 
Thus a $q_{p}$ value of II.50 (Table 5 ) in continuous culture becomes $2 \cdot 13$ when expressed as rate of production per extinction unit instead of as $\mathrm{mg} / \mathrm{ml}$. This can be compared with a $q_{p}$ of $2 \cdot \mathrm{I}$ in batch culture (Table $\mathrm{I}$ ). The active production of enterotoxin $\mathrm{B}$ during balanced growth in continuous culture is not consistent with the view that enterotoxin B is a secondary metabolite produced after the logarithmic phase of growth has been largely completed (Markus \& Silverman, 1969). It is, however, in agreement with the more recent finding of Czop \& Bergdoll (1974) that the rate of enterotoxin B production by strain s6 during exponential growth was extremely high in batch culture.

Lipase, deoxyribonuclease and TEP production also increased with increase in growth rate under conditions of continuous culture, but except for lipase the increases were much less marked than with enterotoxin. A direct relationship thus exists between the growth rate and the specific rates of production of enterotoxin B, lipase and deoxyribonuclease. These findings are consistent with those of Czop \& Bergdoll (I974) that enterotoxin B production increased as the cellular RNA level increased, since the RNA content of cells has been reported to increase with growth rate (Schaechter, Maaløe \& Kjeldgaard, 1958). The production of only one extracellular protein, lysozyme, out of four studied decreased as the growth rate increased. These results are in contrast with those of Coleman (1967) who reported an inverse relationship between the growth rate of Bacillus subtilis and the synthesis of three extracellular enzymes.

Non-replicating cells grown in the absence of glucose produced considerable amounts of enterotoxin. This production was inhibited by chloramphenicol, indicating that new protein synthesis was required for enterotoxin production. However, enterotoxin production was not repressed by the presence of glucose in the resuspension medium, although $\beta$-galactosidase synthesis was almost completely inhibited. This suggests that glucose repression of enterotoxins is not mediated in the same way as the repression of $\beta$-galactosidase. Catabolite repression may nevertheless be important, since other workers have reported that catabolite repression of protein synthesis may be mediated in different ways in the same organism (Tanaka \& Iuchi, I97I ; Rotham-denes, Hesse \& Epstein, 1973). However, inhibition of inducer entry is a significant factor in the regulation of the gal operon in Escherichia coli (Paigen \& Williams, 1970) and may be responsible for glucose repression of $\beta$-galactosidase production by staphylococci. Enterotoxin production does not require an exogenous inducer and so would not be subject to this type of repression.

Staphylococci grown in glucose, on the other hand, produced greatly decreased amounts of enterotoxins $\mathbf{B}$ and $\mathbf{C}$, and $\beta$-galactosidase, when resuspended in the absence of glucose. Such cells may therefore lack some compound necessary for the production of all catabolite repressible proteins. Cyclic AMP has been reported to play such a role in catabolite repression in E. coli (De Crombrugghe, Perlman, Varmus, \& Pastan 1969).

We are indebted to M. S. Bergdoll (University of Wisconsin, Madison, Wisconsin, U.S.A.) for supplying strains 100 , s6 and $36 \mathrm{I}$, and enterotoxins $\mathrm{A}, \mathrm{B}$ and $\mathrm{C}$ and their corresponding antisera, and to B. Hodren for skilled technical assistance. 


\section{REFERENCES}

Blumenthal, H. V. (1972). Glucose catabolism in staphyloccocci. In The Staphylococci, pp. I13-135. Edited by J. A. Cohen. New York: John Wiley.

Chesbro, W. R., Heydrick, F. P., Martineau, R. \& Perkins, G. N. (1965). Purification of staphyloc sccal $\beta$-haemolysin and action on staphylococcal and streptococcal cell walls. Journal of Bacteriology $\mathbf{8 9}$, 378-389.

Coleman, G. (1967). Studies on the regulation of extracellular enzyme formation by Bacillus subtilis. Journal of General Microbiology 49, 42 I-43I.

Czop, J. K. \& Bergdoll, M.S. (1974). Staphylococcal enterotoxin synthesis during the exponential, transitional, and stationary growth phases. Infection and Immunity 9, 229-235.

De Crombrugghie, B., Perlman, R. L., Varmus, H. E. \& Pastan, I. (1969). Regulation of inducible enzyme synthesis in Escherichia coli by cyclic adenosine 3',5'-monophosphate. Journal of Biological Chemistry 244, 5828-5835.

Dornbusch, K. \& Hallander, H. O. (1973). Transduction of penicillinase production and methicillin resistance - enterotoxin B production in strains of Staphylococcus aureus. Journal of General Microbiology 76, I-I I.

EAGon, R. G. (1968). Advances in General Microbiology Methods. Minneapolis: Burgess Publishing Co.

Forsgren, A., Nordström, K., Philipson, L. \& Suöquist, J. (I97I). Protein A mutants of Staphylococcus aureus. Journal of Bacteriology 107, 245-250.

GALlo, M. \& KATZ, E. (1972). Regulation of secondary metabolite biosynthesis: catabolite repression of phenoxazinone synthase and actinomycin formation by glucose. Journal of Bacteriology rog, 659-667.

Herbert, D., Elsworth, R. \& Telling, R. C. (I956). The continuous culture of bacteria; a theoretical and experimental study. Journal of General Microbiology 14, 60I-622.

Jarvis, A. W., Lawrence, R. C. \& Pritchard, G. G. (1973). Production of staphylococcal enterotoxins A, $\mathrm{B}$ and $\mathrm{C}$ under conditions of controlled $\mathrm{pH}$ and aeration. Infection and Immunity $7,847-854$.

MANDElstam, J. (1962). The repression of constitutive $\beta$-galactosidase in Escherichia coli by glucose and other carbon sources. Biochemical Journal 82, 489-493.

MarkUS, Z. \& Silverman, G. J. (1969). Enterotoxin B synthesis by replicating and non-replicating cells of Staphylococcus aureus. Journal of Bacteriology 97, 506-51 2.

Metzger, J. F., Johnson, A. D., Collins, W. S., II \& McGanN, V. (I973). Staphylococcus aureus enterotoxin B release (excretion) under controlled conditions of fermentation. Applied Microbiology 25, 770-773.

Miller, R. D. \& FunG, D. Y. C. (I973). Amino-acid requirements for the production of enterotoxin B by Staphylococcus aureus. Applied Microbiology 25, 800-806.

Morse, S. A. \& Baldwin, J. N. (I971). Regulation of staphylococcal enterotoxin B: effect of thiamine starvation. Applied Microbiology 22, 242-249.

Morse, S. A., MaH, R. A. \& Dobrogosz, W. J. (1969). Regulation of staphylococcal enterotoxin B. Journal of Bacteriology 98, 4-9.

OMENN, G. S. \& Friedman, J. (1970). Isolation of mutants of Staphylococcus aureus lacking extracellular nuclease activity. Journal of Bacteriology 101, $921-924$.

Paigen, K. \& Williams, B. (I970). Catabolite repression and other control mechanisms in carbohydrate utilization. In Advances in Microbial Physiology, vol. 4, pp. 25I-324. Edited by A. H. Rose and J. F. Wilkinson. London: Academic Press.

PIRT, S. J. (1969). Microbial growth and product formation. In Microbial growth, pp. 199-221. Edited by P. M. Meadow and S. J. Pirt. Cambridge: Cambridge University Press.

Rotham-denes, L. B., Hesse, J. E. \& Epstein, H. (1973). Role of cyclic adenosine 3' 5'-monophosphate in the in vivo expression of the galactose operon of Escherichia coli. Journal of Bacteriology 114, 1040-1044.

Schaechter, M., MaAløe, O. \& KJeldgaARd, N. O. (1958). Dependency on medium and temperature of cell size and chemical composition during balanced growth of Salmonella typhimurium. Journal of General Microbiology 19, 592-606.

Stanier, R. Y., Doudoroff, M. \& Adelberg, E. A. (I971). General Microbiology, 3rd ed. London: Macmillan.

TANAKA, S. \& IUCHI, S. (I971). Induction and repression of an extracellular protease of Vibrio parahaemolyticus. Biken Journal 14, 8I-96.

Wu, C.-H. \& Bergdoll, M. S. (1971). Stimulation of enterotoxin B production. II. Synthetic medium for staphylococcal growth and enterotoxin B production. Infection and Immunity 3, 784-792.

YANo, T. \& KogA, S. (1973). Dynamic behaviour of the chemostat subject to product inhibition. Journal of General and Applied Microbiology 19, 97-1 I4. 